\title{
Systematic review of the treatment of upper respiratory tract infection
}

\author{
Tom Fahey, Nigel Stocks, Toby Thomas
}

\begin{abstract}
Objectives-To assess the risks and benefits of antibiotic treatment in children with symptoms of upper respiratory tract infection (URTI).

Design-Quantitative systematic review of randomised trials that compare antibiotic treatment with placebo.

Data sources-Twelve trials retrieved from a systematic search (electronic databases, contact with authors, contact with drug manufacturers, reference lists); no restriction on language.
\end{abstract}

Main outcome measures-The proportion of children in whom the clinical outcome was worse or unchanged; the proportion of children who suffered complications or progression of illness; the proportion of children who had side effects.

Results-1699 children were randomised in six trials that contributed to the meta-analysis. Six trials were not used in the meta-analysis because of different outcomes or incomplete data. Clinical outcome was not improved by antibiotic treatment (relative risk $1.01,95 \%$ confidence interval (CI) 0.90 to 1.13 ), neither was the proportion of children suffering from complications or progression of illness (relative risk $0.71,95 \%$ CI 0.45 to 1.12). Complications from URTI in the five trials that reported this outcome was low (range 2-15\%). Antibiotic treatment was not associated with an increase in side effects compared with placebo (relative risk $0.8,95 \%$ CI 0.54 to 1.21 ).

Conclusions-In view of the lack of efficacy and low complication rates, antibiotic treatment of children with URTI is not supported by current evidence from randomised trials.

(Arch Dis Child 1998;79:225-230)

Division of Primary Care, University of Bristol, Canynge Hall, Whiteladies Road, Bristol BS8 2PR, UK T Fahey

N Stocks

United Medical and Dental Schools, London SE11 6SP, UK T Thomas

Toby Thomas died in a road traffic accident on 26 November 1996

Correspondence to: Dr Fahey.

email: tom.fahey@bris.ac.uk

Accepted 9 April 1998 caused by bacteria. ${ }^{2}$ URTI forms a continuum with lower respiratory tract infection, which is
Keywords: respiratory tract infections; systematic re-

Upper respiratory tract infection (URTI) in children is a common illness and accounts for a ily doctors in the UK. The fourth Nat dren aged $0-4$ and 5-15 years, respectively. ${ }^{1}$ The clinical syndrome of URTI comprises a variety of symptoms - most frequently cough and coryza associated with fever. The cause is more often associated with bacterial infection. Haemophilus influenzae and Streptococcus pneumoniae are cultured in approximately $20 \%$ of children with lower respiratory tract infection in the community.

Despite the predominantly viral cause, antibiotics are frequently prescribed to children with symptoms of URTI. ${ }^{4}$ On average, $40 \%$ of children with URTI are prescribed an antibiotic, but this varies substantially between doctors, with some general practitioners prescribing to as many as $60 \%$ of children who present with URTI. ${ }^{4}$ Such prescribing is initiated by general practitioners in the belief that antibiotics may either ameliorate symptoms, shorten the illness, or prevent further complications, such as pneumonia or acute otitis media. This belief is not based on any firm evidence from clinical trials. In fact, previous narrative reviews have suggested that for most children URTI is a self limiting condition that requires symptomatic treatment alone, and that antibiotic treatment is more likely to cause harm than benefit. $^{56}$

In view of the persistence of antibiotic prescribing for this condition and the uncertainty concerning the risks and benefits from treatment, we performed a quantitative systematic review of randomised controlled trials (RCTs) that compared antibiotic treatment with placebo in children with URTI managed in community settings.

\section{Methods}

INCLUSION AND EXCLUSION CRITERIA

We included studies of infants and children aged 0-12 years who were attending a family practice clinic, hospital based outpatient department, or community based health clinic, with onset of acute upper respiratory illness in the previous two weeks. The definition of URTI was a pragmatic one. We included studies of children with non-specific symptoms referable to the respiratory tract, which had not been treated in the preceding week with antibiotics. Therefore, we accorded with the definition of the International Classification of Health Problems in Primary Care (ICHPPC2), which defines URTI as the acute inflammation of nasal or pharyngeal mucosa in the absence of other specifically defined respiratory infection. ${ }^{7}$ The studies included were prospective RCTs where antibiotic was allocated by formal randomisation or by quasirandomisation such as alternation, to treatment and placebo groups. Only placebo controlled trials were included, comparative studies between different classes of antibiotics were excluded. The outcomes in this review 
Table 1 Characteristics of population, diagnostic labels, and clinical features

\begin{tabular}{|c|c|c|c|c|c|c|}
\hline Trial & $\begin{array}{l}\text { Year } \\
\text { published }\end{array}$ & $\begin{array}{l}\text { Number of } \\
\text { participants }\end{array}$ & Age of children & Setting & Diagnostic label & Clinical features \\
\hline $\operatorname{Hardy}^{17}$ & 1956 & $\begin{array}{l}217 \text { randomised, } \\
118 \text { male, } 99 \\
\text { female; } 149 \\
\text { analysed ( } 68.7 \% \\
\text { follow up) }\end{array}$ & 0 to 13 years & Outpatient clinic & $\begin{array}{l}\text { Uncomplicated respiratory } \\
\text { infections }\end{array}$ & $\begin{array}{l}\text { Fever } \geqslant 38^{\circ} \mathrm{C} \\
\text { Negative clinical examination } \\
\text { except for nasopharyngitis }\end{array}$ \\
\hline Townsend ${ }^{24}$ & 1960 & $\begin{array}{l}845 \text { children (total } \\
\text { number of cases } \\
\text { seen in } 1884 \text { ) }\end{array}$ & 2 months to 12 years & $\begin{array}{l}\text { Private US paediatric } \\
\text { practice }\end{array}$ & $\begin{array}{l}\text { Suspected viral respiratory } \\
\text { infection }\end{array}$ & Not reported \\
\hline Wynn-Williams $^{25}$ & ${ }^{5} 1961$ & 96 children & 2 to 12 years & $\begin{array}{l}\text { Community setting in } \\
\text { UK }\end{array}$ & $\begin{array}{l}\text { Families selected and then } \\
\text { randomised from children } \\
\text { with "past history of } \\
\text { frequent colds going onto } \\
\text { the chest". Initiation of } \\
\text { treatment if mother } \\
\text { suspected URI in child } \\
\text { "severe enough to put child } \\
\text { to bed or prevent } \\
\text { attendance at school" }\end{array}$ & Not reported \\
\hline Townsend $^{23}$ & 1962 & 781 children & 0 to 12 years & $\begin{array}{l}\text { Private US paediatric } \\
\text { practice }\end{array}$ & $\begin{array}{l}\text { Children with a "febrile } \\
\text { respiratory illness" }\end{array}$ & $\begin{array}{l}\text { All "presented signs and } \\
\text { symptoms of the respiratory } \\
\text { system". Cases further classified } \\
\text { into measles, croup, and others }\end{array}$ \\
\hline Ackerman $^{18}$ & 1968 & 60 children & 3 to 12 months & US army dispensary & $\begin{array}{l}\text { Undifferentiated respiratory } \\
\text { infection }\end{array}$ & $\begin{array}{l}\text { Acute change in state of health } \\
\text { Undifferentiated symptoms of } \\
\text { URI } \\
\text { Rectal temperature }>38^{\circ} \mathrm{C}\end{array}$ \\
\hline Lexomboon $^{19}$ & 1971 & 174 children & $\begin{array}{l}6 \text { months to } 12 \text { years } \\
\text { (half }<2 \text { years) }\end{array}$ & $\begin{array}{l}\text { Outpatient department } \\
\text { hospital in Thailand }\end{array}$ & Upper respiratory infection & $\begin{array}{l}\text { Fever } \geqslant 39^{\circ} \mathrm{C} \\
\text { Symptoms of RTI }<48 \mathrm{~h}\end{array}$ \\
\hline Gordon $^{26}$ & 1974 & 89 children & $<2$ years to 6 years & $\begin{array}{l}\text { A \& E department in } \\
\text { children's hospital, } \\
\text { Australia }\end{array}$ & Minor respiratory illness & $\begin{array}{l}\text { Symptoms referable to } \\
\text { respiratory tract, most had cough } \\
\text { and running nose, no antibiotic } \\
\text { in previous week }\end{array}$ \\
\hline Taylor $^{20}$ & 1977 & 197 children & 2 to 10 years & $\begin{array}{l}\text { Suburban general } \\
\text { practice in New } \\
\text { Zealand }\end{array}$ & $\begin{array}{l}\text { Presumed viral respiratory } \\
\text { infections }\end{array}$ & $\begin{array}{l}\text { Classified as having } \\
\text { nasopharyngitis }(42), \\
\text { pharyngo-tonsillitis (71), } \\
\text { bronchitis or } \\
\text { laryngotracheo-bronchitis }(84)\end{array}$ \\
\hline Todd $^{21}$ & 1984 & 142 children & $\begin{array}{l}>2 \text { months; mean } \\
\text { (SD) } 2 \text { (2) years }\end{array}$ & $\begin{array}{l}2 \text { paediatric offices and } \\
1 \text { clinic in army base in } \\
\text { US }\end{array}$ & Purulent nasopharyngitis & $\begin{array}{l}\text { All had purulent nasal discharge } \\
\text { with or without other signs of } \\
\text { respiratory illness }\end{array}$ \\
\hline Sutrisna $^{22}$ & 1991 & 900 children & $\begin{array}{l}<5 \text { years; } 38 \% \\
\text { (antibiotic) } 35 \% \\
\text { (placebo) were } \\
\text { infants }\end{array}$ & $\begin{array}{l}\text { Health clinics in } \\
\text { Indonesia }\end{array}$ & $\begin{array}{l}\text { Mild acute respiratory } \\
\text { infection }\end{array}$ & $\begin{array}{l}\text { Mild acute respiratory infection } \\
\text { defined according to WHO } \\
\text { criteria: mild upper respiratory } \\
\text { signs such as cough, runny nose } \\
\text { and/or fever }\left(>37^{\circ} \mathrm{C}\right) \text { Respiratory } \\
\text { rate }<50 / \mathrm{min}\end{array}$ \\
\hline Darelid $^{15 \star}$ & 1993 & 88 children & 6 months to 6 years & $\begin{array}{l}3 \text { paediatric outpatient } \\
\text { departments in } \\
\text { Sweden }\end{array}$ & $\begin{array}{l}\text { Longstanding Moraxella } \\
\text { catarrhalis associated cough }\end{array}$ & $\begin{array}{l}\text { Persistent cough }>10 \text { days } \\
\text { seeking medical help. Excluded } \\
\text { clinically suspected pertussis } \\
\text { (known exposure or whooping) }\end{array}$ \\
\hline Gottfarb $^{16 \star}$ & 1994 & 37 children & 7 months to 7 years & $\begin{array}{l}3 \text { paediatric outpatient } \\
\text { departments in } \\
\text { Sweden }\end{array}$ & Persistent cough & $\begin{array}{l}\text { Lower respiratory infection with } \\
\text { cough for a minimum of } 10 \text { days. } \\
\text { Children with frequent cough, } \\
\geqslant 11 \text { coughing attacks } / 24 \text { h were } \\
\text { included }\end{array}$ \\
\hline
\end{tabular}

${ }^{\star}$ Not included in the principal results of the meta-analysis.

were: the proportion of children in whom clinical outcome was worse or unchanged at day $5-7$; the proportion of children who suffered complications or progression of illness (defined in individual trials as either otitis media or progression of respiratory symptoms including pharyngitis, bronchitis or pneumonia); and the proportion of children who had side effects (including diarrhoea and vomiting, rashes, hyperactivity, and stomatitis).

SYSTEMATIC SEARCH

We searched MEDLINE and EMBASE databases from 1966 and 1982, respectively, using the recommended Cochrane Collaboration search strategy, ${ }^{8}$ using the following Medical Subject Headings (MESH) terms: cough, bronchitis, sputum, respiratory tract infection. The search was not restricted to the English language. We also searched for references from published research by using Science Citation Index and searching references in published studies and abstracts, particularly for those published before 1966. We conducted a search on the controlled trials register from the Cochrane Library, ${ }^{9}$ using the search terms bronchitis, chest infection or common cold. We contacted authors of published RCTs requesting knowledge of any unpublished studies. We also wrote to all UK drug companies who manufacture antibiotics according to the British National Formulary requesting unpublished RCTs.

QUALITY ASSESSMENT AND EXTRACTION OF DATA Each trial was read independently by two authors who then assessed the quality of each study according to the four criteria outlined in the Cochrane collaboration handbook. ${ }^{10}$ Each criterion-selection bias, performance bias, attrition bias, and detection bias-was scored from 1 to 3 , so the highest score for an individual trial was 12 . Measurement of agreement between reviewers was calculated by 
Table 2 Interventions, outcomes, and quality of trials

\begin{tabular}{|c|c|c|c|c|c|c|}
\hline Trial & Antibiotic dosage & $\begin{array}{l}\text { Antibiotic } \\
\text { duration }\end{array}$ & Outcomes measured & $\begin{array}{l}\text { Contribution to } \\
\text { meta-analysis }\end{array}$ & Quality & Favours antibiotic? \\
\hline $\mathrm{Hardy}^{17}$ & $\begin{array}{l}\text { Gantrisin, penicillin or } \\
\text { aureomycin, dosage not stated } \\
\text { but antibiotic given "adjusting the } \\
\text { dosage according to a } \\
\text { predetermined scale, based on } \\
\text { weight and age". Given qid }\end{array}$ & 4 days & $\begin{array}{l}\text { Complication rate in a two } \\
\text { week period }\end{array}$ & Yes, outcome 2 & 7 & No \\
\hline Townsend $^{24}$ & $\begin{array}{l}\text { Sulphonamides } 0.1 \mathrm{~g} / \mathrm{kg} / 24 \mathrm{~h} \\
\text { Tetracyclines } 40-50 \mathrm{mg} / \mathrm{kg} / 24 \mathrm{~h} \\
\text { Another group of children } \\
\text { randomised to "prophylactic" } \\
\text { treatment, of same drugs at } \\
\text { "approximately 1/4 of the } \\
\text { therapeutic dose". }\end{array}$ & Not stated & Complication rate & No & 4 & No \\
\hline Wynn-Williams $^{25}$ & $\begin{array}{l}\text { Tetracycline given tid in the } \\
\text { following dose: age } 2: 40 \mathrm{mg} \text {; age } \\
3 \text { and } 4: 50 \mathrm{mg} \text {; age } 5 \text { and } 6: 75 \\
\mathrm{mg} \text {; age } 7 \text { and } 8: 100 \mathrm{mg} \text {; ages } 9 \\
\text { to } 12: 150 \mathrm{mg}\end{array}$ & 2 days & $\begin{array}{l}\text { Subsequent URIs (measured as } \\
\text { episodes) } \\
\text { Average duration of symptoms }\end{array}$ & No & 7 & Yes \\
\hline Townsend $^{23}$ & $\begin{array}{l}\text { Sulphonamides }(0.5 \mathrm{~g} \text { per } \\
\text { teaspoonful) } \\
\text { Tetracycline ( } 125 \mathrm{mg} \text { per } \\
\text { teaspoonful) } \\
\text { Chloramphenicol }(125 \mathrm{mg} \text { per } \\
\text { teaspoonful) } \\
\text { Penicillin }(200000 \text { units per } \\
\text { teaspoonful) } \\
\text { All given by a dosage schedule }\end{array}$ & $\begin{array}{l}\text { For as long as } \\
\text { child was } \\
\text { febrile }\end{array}$ & Not given & No & 6 & No \\
\hline Ackerman $^{18}$ & $\begin{array}{l}\text { Penicillin V ( } 100000 \text { units qid) } \\
\text { Tetracycline } 50 \mathrm{mg} \text { qid) }\end{array}$ & 10 days & $\begin{array}{l}\text { Clinical state at follow up } \\
(48 \mathrm{~h}) \\
\text { Progression of initial symptoms } \\
\text { Mean duration of respiratory } \\
\text { morbidity } \\
\text { Continuous respiratory } \\
\text { symptoms (day } 7) \\
\text { "Complications" (side effects) }\end{array}$ & $\begin{array}{l}\text { Yes, outcome 1, } 2 \text {, } \\
\text { and } 3\end{array}$ & 10 & No \\
\hline Lexomboon $^{19}$ & $\begin{array}{l}\text { Penicillin } 30 \mathrm{mg} / \mathrm{kg} / \text { day } \\
\text { Tetracycline } 40 \mathrm{mg} / \mathrm{kg} / \text { day }\end{array}$ & 7 days & Clinical outcome (day 7) & Yes, outcome 1 & 7 & No \\
\hline Gordon $^{26}$ & $\begin{array}{l}\text { Penicillin } \\
\text { Ampicillin } \\
\text { Erythromycin } \\
\text { Dosage } 125 \mathrm{mg} / 5 \mathrm{ml} \\
\text { Age }<2 \text { years: } 3 \text { to } 5 \mathrm{ml} \text { qid } \\
\text { Older children: } 5 \text { to } 10 \mathrm{ml} \text { qid }\end{array}$ & Not stated & $\begin{array}{l}\text { Relief of symptoms } \\
\text { Improvement of physical signs }\end{array}$ & No & 5 & No \\
\hline Taylor $^{20}$ & $\begin{array}{l}\text { Amoxycillin }(125 \mathrm{ml} / 5 \mathrm{ml} \text { ) } \\
\text { Co-trimoxazole } \\
\text { (sulphamethoxazole } 200 \mathrm{mg} \text { and } \\
\text { trimethoprim } 40 \mathrm{mg} / 5 \mathrm{ml} \text { ) }\end{array}$ & 5 days & $\begin{array}{l}\text { Treatment failure } \\
\text { Symptoms at day } 8 \\
\text { Not returned to normal activity } \\
\text { day } 8 \\
\text { Side effects }\end{array}$ & $\begin{array}{l}\text { Yes, outcomes 1, } 2 \text {, } \\
\text { and } 3\end{array}$ & 8 & $\begin{array}{l}\text { Yes (treatment failure) } \\
\text { No (other outcomes) }\end{array}$ \\
\hline $\operatorname{Todd}^{21}$ & Cephalexin $25-50 \mathrm{mg} / \mathrm{kg} /$ day & 5 to 6 days & $\begin{array}{l}\text { Assessed at day } 5 \text { to } 6 \\
\text { Parent assessed: drug benefit } \\
\text { drug side effects } \\
\text { Physician assessed: fever nasal } \\
\text { discharge complications }\end{array}$ & $\begin{array}{l}\text { Yes, outcomes 1,2, } \\
\text { and } 3\end{array}$ & 9 & No \\
\hline Sutrisna $^{22}$ & Ampicillin $(25-30 \mathrm{mg} / \mathrm{kg})$ qid & 5 days & $\begin{array}{l}\text { Clinical outcome at } 5-7 \text { and } 14 \\
\text { days } \\
\text { Side effects }\end{array}$ & $\begin{array}{l}\text { Yes, outcomes } 1 \text { and } \\
3\end{array}$ & 7 & No \\
\hline Darelid $^{15 \star}$ & $\begin{array}{l}\text { Erythromycin suspension } \\
50 \mathrm{mg} / \mathrm{kg} / \text { day }\end{array}$ & 7 days & $\begin{array}{l}\text { Cough at } 7 \text { days } \\
\text { Worsening cough, fever and } \\
\text { purulent sputum } \\
\text { Side effects }\end{array}$ & No & 8 & $\begin{array}{l}\text { Yes, but open trial, } \\
\text { parent and } \\
\text { investigator knew } \\
\text { treatment assignment }\end{array}$ \\
\hline Gottfarb $^{16 \star}$ & $\begin{array}{l}\text { Amoxycillin/clavulanic acid } \\
20 \mathrm{mg} / \mathrm{kg} / \text { day }\end{array}$ & 7 days & $\begin{array}{l}\text { Number of coughing attacks } \\
\text { each day for } 8 \text { days } \\
\text { Clinical improvement judged by } \\
\text { parents day } 12 \\
\text { Clinical improvement judged by } \\
\text { doctor day } 12\end{array}$ & No & 6 & Yes \\
\hline
\end{tabular}

Outcomes coded as follows:

1 , the proportion of children in whom the clinical outcome is unchanged or worse.

2 , the proportion of children who suffered complications or progression of illness.

3 , the proportion of children who had suffered side effects from taking antibiotic or placebo.

${ }^{\star}$ Not included in the principal results of the meta-analysis.

means of the $\kappa$ statistic and disagreement resolved by consensus. Data were extracted independently and where data were missing or incomplete the authors of the trial were contacted and clarification was sought.

ANALYSIS

Statistical and clinical significance was evaluated by means of estimating relative risk. ${ }^{11}$ The magnitude of baseline risk and heterogeneity between studies was explored by means of a
L'Abbe graph. ${ }^{12}$ Pooled relative risks were estimated with $95 \%$ confidence intervals (CI) by means of a fixed effects model..$^{13}$ Relative risks and pooling of data were calculated with REVMAN 3.0 (Update Software 1996, Oxford, $\mathrm{UK})$.

\section{Results}

TRIALS FOUND AND QUALITY RATING

We found 12 randomised trials that matched the inclusion criteria of the study (tables 1 and 

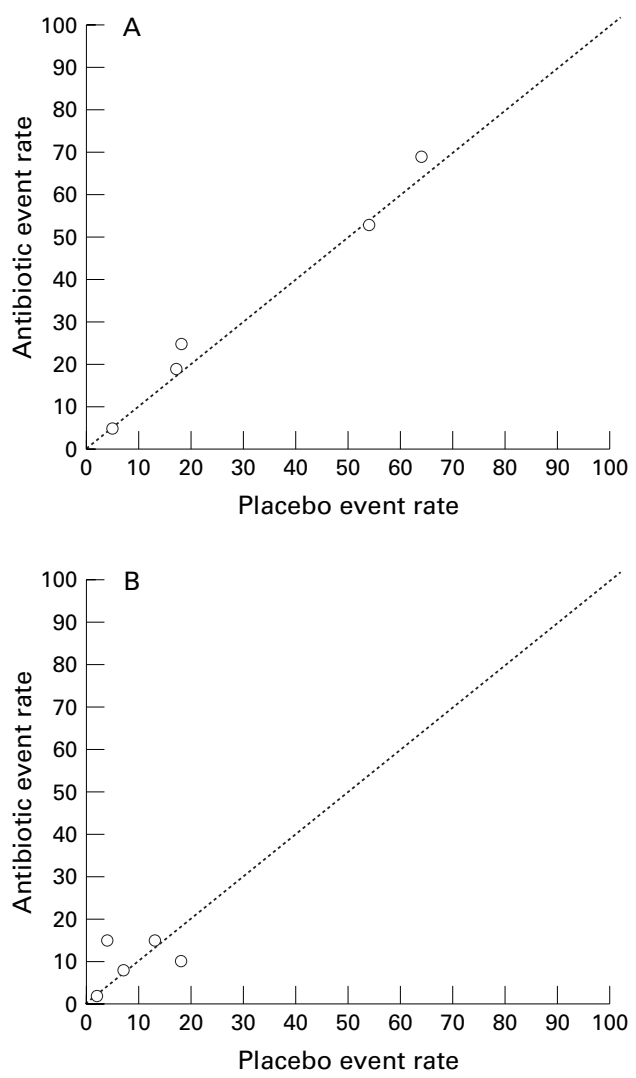

Figure 1 L'Abbe plots of the proportion of children in whom $(A)$ the clinical outcome was worse or unchanged and (B) who suffered complications or progression of illness.

2). A further unpublished RCT from the 1950 s was mentioned in a report from a conference proceeding, ${ }^{14}$ but we were unable to secure any data from this study (unable to contact authors). Of the 12 studies, two were concerned with management of URTI in children with persistent cough ( $>10$ days), ${ }^{15}$

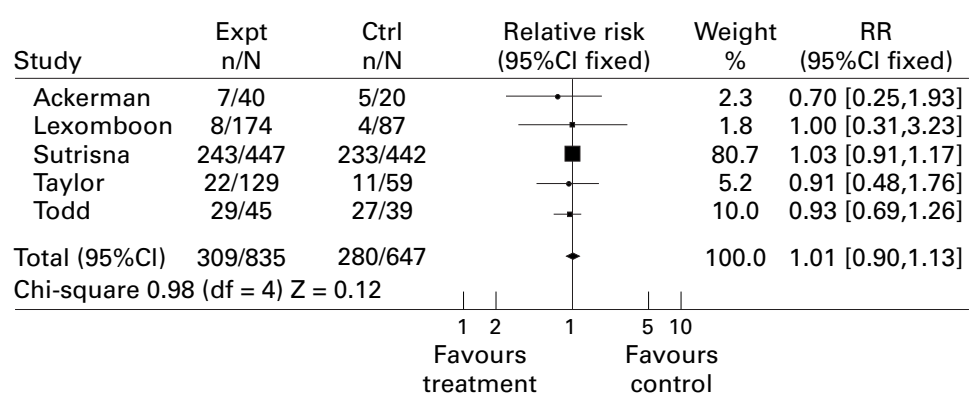

Figure 2 Clinical outcome worse or unchanged in children with upper respiratory tract infection treated with antibiotic $v$ placebo.

\begin{tabular}{|c|c|c|c|c|c|c|}
\hline Study & $\begin{array}{l}\text { Expt } \\
\mathrm{n} / \mathrm{N}\end{array}$ & $\begin{array}{l}\mathrm{Ctrl} \\
\mathrm{n} / \mathrm{N}\end{array}$ & \multicolumn{2}{|c|}{$\begin{array}{l}\text { Relative risk } \\
(95 \% \mathrm{Cl} \text { fixed) }\end{array}$} & \multirow{2}{*}{$\begin{array}{c}\begin{array}{c}\text { Weight } \\
\%\end{array} \\
7.3\end{array}$} & \multirow{2}{*}{$\begin{array}{c}\mathrm{RR} \\
\text { (95\%Cl fixed) } \\
1.75[0.40,7.66]\end{array}$} \\
\hline Ackerman & $7 / 40$ & $2 / 20$ & & & & \\
\hline Hardy & $19 / 149$ & $10 / 68$ & $\rightarrow$ & & 37.6 & $0.87[0$ \\
\hline Lexomboon & $3 / 174$ & $2 / 8$ & - & & 7.3 & $0.75[0$. \\
\hline Taylor & $5 / 1$ & $10 / 66$ & $\longleftarrow$ & & 36.5 & $0.25[0$ \\
\hline Todd & $4 / 5$ & $4 / 52$ & & & 11.3 & $0.71[0.25,3.59]$ \\
\hline Total $(95 \% \mathrm{Cl})$ & $38 / 549$ & $28 / 293$ & & & 100.0 & $0.71[0.45,1.12]$ \\
\hline \multicolumn{3}{|c|}{ Chi-square $5.79(\mathrm{df}=4) \mathrm{Z}=1.46$} & & & & \\
\hline & & & $\begin{array}{l}12 \\
\text { vours } \\
\text { atment }\end{array}$ & & & \\
\hline
\end{tabular}

Figure 3 Subsequent complications or progression of illness in children with upper respiratory tract infection treated with antibiotic $v$ placebo.

\section{Key messages}

- Antibiotic treatment did not alter clinical outcome or reduce complication rates in children with upper respiratory tract infections

- Side effects were similar in antibiotic treatment and placebo groups

- Complications from upper respiratory tract infections are low (2-15\%)

- Larger trials are needed to establish whether antibiotic treatment reduces complications in children with upper respiratory tract infections

and in view of the different characteristics of the children at the time of recruitment these were not included in the principal results of the meta-analysis. Both of these trials reported that antibiotic treatment has a beneficial effect on clinical outcome (table 2).

Of the 10 remaining RCTs, six contributed data to the meta-analysis. ${ }^{17-22}$ The other four RCTs did not contribute data because the outcome was reported as a rate, with no actual data on the number of children assessed at the end of the trial. ${ }^{23-26}$ Three of these four trials reported that antibiotic treatment had no effect on either relief of symptoms or subsequent complications in children (table 2). ${ }^{232426}$

The quality of RCTs was variable, with a range of 4 to 10 in terms of overall quality score. The $\kappa$ score for the between-investigator assessment of RCT quality was 0.79 indicating a substantial agreement in quality rating of the separate RCTs.

\section{BASELINE RISK AND DIAGNOSIS}

There was a substantial difference between individual RCTs in the proportion of children in whom the clinical outcome was worse or unchanged (range in placebo arms of individual trials 5-69\%) (fig 1). This finding highlights the heterogeneous nature of the participants in each of the studies in terms of the natural resolution from URTI. In contrast, the baseline risk for progression of illness or further complications was less variable (range $2-15 \%$ ) (fig 1).

EFFICACY AND SIDE EFFECTS OF ANTIBIOTIC Clinical condition worse or unchanged at follow up (relative risk 1.01, 95\% CI 0.90 to 1.13) and complications or progression of illness (relative risk $0.71,95 \%$ CI 0.45 to 1.12 ) were different for antibiotic treatment and placebo groups (figs 2 and 3). The complications from illness were not reported at a uniform time interval in all studies, the maximum time of reporting after initial treatment was two weeks. ${ }^{17}$ Side effects from treatment were not significantly associated with antibiotic use (relative risk $0.8,95 \%$ CI 0.54 to 1.21 ) (fig 4 ).

\section{Discussion}

This review demonstrates that antibiotic treatment of children with URTI does not alter the clinical outcome of the illness or prevent 


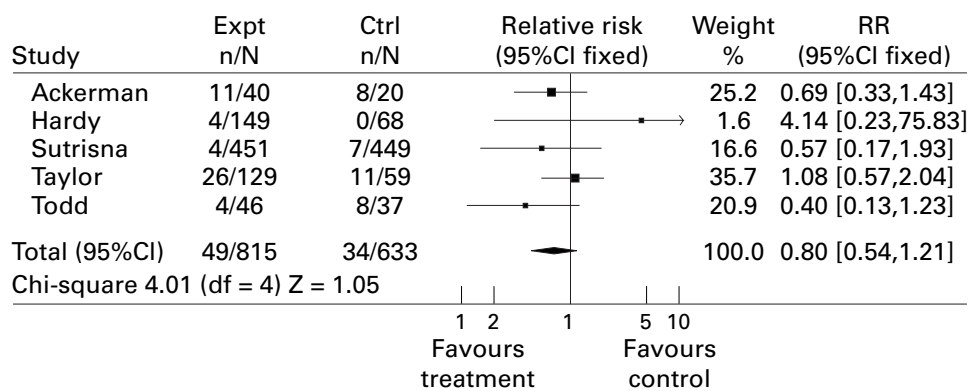

Figure 4 Side effects of treatment in children with upper respiratory tract infection treated with antibiotic v placebo. trial had been published some years ago and the published report did not contain usable data. ${ }^{23-26}$ Only one of these trials reported a positive effect of antibiotic treatment. ${ }^{25}$ Lastly, two trials reported a beneficial effect of antibiotic treatment but were not included in the pooled analysis in this review. ${ }^{15}{ }^{16}$ In view of the small number of patients recruited to these two RCTs and the fact that one trial was an unblinded study, assessment of efficacy in children with persistent cough requires further evaluation before antibiotic treatment can be recommended for these children.

Why do general practitioners continue to prescribe antibiotics for URTI? First, they may be too cautious when managing URTI, overestimating the likely complications, with a lowered threshold for antibiotic prescribing. Second, general practitioners may feel that parents of children with URTI expect a prescription for an antibiotic. Evidence from adults presenting with URTI refutes this assumption. ${ }^{28}$ Patients with URTI are more satisfied when doctors explain the nature of likely course of their illness. ${ }^{28}$ Qualitative work has demonstrated that parents of young children with acute illness were more dissatisfied when doctors provided inadequate information about the likely course of the illness. ${ }^{29}$ Thus, like the management of acute otitis media, the management of URTI should be reassessed in terms of the natural course of the illness and the low rate of complications. ${ }^{30}$

There are other serious consequences that need to be considered in the context of a policy of prescribing antibiotics for URTI. Observational research has shown that $24 \%$ of children are re-evaluated by a general practitioner during the same episode of URTI. ${ }^{4}$ Antibiotic use in adults with sore throat "medicalises" a self limiting condition and increases patient expectation for reattendance and antibiotic treatment when a recurrent episode of illness occurs. ${ }^{31}$ It seems likely that continuing to prescribe antibiotics for URTI is likely to increase parental expectations, influencing both prescribing and reattendance rates. Lastly, antibiotic use in the UK is increasing and is associated with the emergence of resistant organisms. ${ }^{32}{ }^{33}$ These considerations emphasise that antibiotic treatment is not a risk free policy ${ }^{34}$; careful measurement of the likely benefit and harm of treatment is required for all cases of URTI. ${ }^{35}$

In conclusion, URTI in children is usually a self limiting condition with complications occurring in approximately $10 \%$ of cases. Antibiotic treatment does not influence either the course of illness or the likelihood of suffering complications. In view of the adverse effects on reattendance, "medicalisation" of a self limiting condition, costs of treatment, and impact on antibiotic resistant organisms, the management of URTI should be based on a full explanation of the likely course of the illness to the child's parents, and symptomatic treatment in the first instance.

We thank Matthias Egger, David Jewell, and Debbie Sharp for helpful comments on this paper, and Johan Darelid for clarifica- trials did not provide any data, principally because authors could not be contacted as the 
tion concerning data from his study. This study was funded by The Royal College of General Practitioners Scientific Foundation Board.

1 Royal College of General Practitioners OPCS and Department of Health. Morbidity statistics from general practice.
Fourth national study, 1991-1992. London: HMSO, 1995.

2 Gwaltney JM. The common cold. In: Mandell GL, Bennet JE, Dolin R, eds. Principles and practice of infectious disease. 4th ed. New York: Churchill Livir

3 Turner RB, Lande AE, Chase P, Hilton N, Weinberg D. Pneumonia in pediatric outpatients: cause and clinical manifestations. $\mathcal{F}$ Pediatr 1987;111:194-200.

4 Stott N. Management and outcome of winter upper respiratory tract infections in children aged 0-9 years. BMF 1979 i: $29-31$.

5 Davis SD, Wedgwood RJ. Antibiotic prophylaxis in acute viral respiratory diseases. Am f Dis Child 1965;109:544-53.

6 Soyka LF, Robinson DS, Lachant N, Monaco J. The misuse of antibiotics for treatment of upper respiratory tract infections in children. Pediatrics 1975;55:552-6.

7 World Organisation of National Colleges and Academies of General Practice. An international classification of health problems of primary health care (ICHPPC-2). 3rd ed. Oxford: problems of primary health care (ICH

8 Dickerson K, Scherer R, Lefebvre C. Identifying relevent studies for systematic reviews. In: Chalmers I, Altman D,
eds. Systematic reviews. London: BMJ Publishing Group, eds. Systematic

9 Cochrane Collaboration. The Cochrane library. v. Issue 2. Oxford: Update Software, 1997.

10 Mulrow CD, Oxman AD. Cochrane collaboration handbook (updated 9 December 1996). In: The Cochrane Collaboration, ed. The Cochrane library. Issue 2. Oxford: Update Software, 1996

11 Hennekens C, Buring J. Epidemiology in medicine. Boston: Little Brown and Co, 1987

12 L'Abbe KA, Detsky AS, O'Rourke K. Meta-analysis in clinical research. Ann Intern Med 1987;107:224-33.

13 Petitti DB. Meta-analysis, decision analysis and costeffectiveness analysis. Methods for quantitative synthesis in medicine. New York: Oxford University Press, 1994.

14 Eichenwald HF, Perry HC. Unpublished trial. Cited in pediatric conference. Arch Pediatrics 1960;77:171-87.

15 Darelid J, Lofgren S, Malmvall B. Erythromycin treatment is beneficial for longstanding Moraxella catarrhalis associis beneficial for longstanding Moraxella catarrhalis associ-
ated cough in children. Scand F Infect Dis 1993;25:323-9.

16 Gottfarb P, Brauner A. Children with persistent coughoutcome with treatment and role of Moraxella catarrhalis? Scand F Infect Dis 1994;26:545-51.

17 Hardy LM, Traisman HS. Antibiotics and chemotherapeutic agents in the treatment of uncomplicated respiratory infections in children. F Pediatr 1956;48:146-56.

18 Ackerman B. Treatment of undifferentiated respiratory infections in infants. Clin Pediatr 1968;7:391-5.
19 Lexomboon U, Duangmani C, Kusalasai V, Sunakorn P, Olson LC, Noyes HE. Evaluation of orally administered Olson LC, Noyes HE. Evaluation of orally administered Thai children. $\mathcal{F}$ Pediatr 1971;78:772-8.

20 Taylor B, Abbott GD, Kerr MMcK, Fergusson DM. Amoxycillin and co-trimoxazole in presumed viral respiratory infections of childhood:placebo-controlled trial. BMF 1977;ii:552-4.

21 Todd JK, Todd N, Damato J, Todd W. Bacteriology and treatment of purulent nasopharyngitis: a double blind, placebo-controlled evaluation. Pediatr Infect Dis 7 1984;3: 226-32.

22 Sutrisna B, Frerichs RR, Reingold AL. Randomised controlled trial of effectiveness of ampicillin in mild acute repiratory infections in Indonesian children. Lancet 1991; 338:471-4.

23 Townsend EH, Radebaugh JF. Prevention of complications of respiratory illnesses in pediatric practice. $N \mathrm{Engl} \mathcal{F} \mathrm{Med}$ 1962;266:683-9.

24 Townsend EH. Chemoprophylaxis during respiratory infection in private practice. Am ₹ Dis Child 1960;34:566-73.

25 Wynn-Williams N. Control of respiratory infections in children by tetracycline. BMF 1961;i:469-70.

26 Gordon M, Lovell S, Dugdale A. The value of antibiotics in minor

27 Egger M, Davey Smith G, Schneider M, Minder C. Bias in meta-analysis detected by a simple graphical test. $B M \mathcal{F}$ 1997;315:629-934.

28 Hamm RM, Hicks RJ, Bemben DA. Antibiotics and respiratory infections:are patients more satisfied when expecta-

29 Kai J. Parents' difficulties and information needs in coping with acute illness in preschool children: a qualitative study. BMF 1996;313:987-90.

30 Froom J, Culpepper L, Jacobs M, et al. Antimicrobials for acute otitis media? A review fromt the International Primary Care Network. BMF 1997;315:98-102.

31 Little P, Gould C, Williamson I, Warner G, Gantley M, Kinmonth AL. Reattendance and complications in a randomised trial of prescribing strategies for sore throat: the medicalising effect of prescribing antibiotics. $B M F$ 1997;315:350-2.

32 Davey PG, Bax RP, Newey J, et al. Growth in the use of antibiotics in the community in England and Scotland in 1980-93. BM7 1996;312:613.

33 Arason VA, Kristinsson KG, Sigurdsson JA, Stefánsdóttir G, Mölstad S, Gudmundsson S. Do antimicrobials increase the carriage rate of penicillin resistant pneumococci in children? Cross sectional prevalence study. BMF 1996;313 387-91.

34 Orton P. Resistant organisms: a dilemma for primary care? Br f Gen Pract 1997;47:415-16.

35 Gilbert R, Logan S. Future prospects for evidence-based child health. Arch Dis Child 1996;75:465-8. 